\title{
Large plasmids encoding antibiotic resistance and localized-like adherence in atypical enteropathogenic Escherichia coli strains
}

\author{
Scarlat S. Silva, Mariane V. Monfardini and Isabel C. A. Scaletsky*
}

\begin{abstract}
Background: In previous studies, we have shown that atypical enteropathogenic Escherichia coli (aEPEC) strains are important diarrheal pathogens among Brazilian children. In the characterization of a collection of 126 aEPEC strains, we identified 29 strains expressing the localized-like adherence (LAL) pattern on HEp-2 cells and harboring large plasmids in the range of 60 to $98 \mathrm{MDa}$. In this study, we examined 18 of these strains for their ability to transfer the LAL phenotype to a E. coli K-12 C600 strain.

Results: In conjugation experiments, using eight strains which were resistant to one or more antimicrobials and positive for F-pili genes (traA), we were able to cotransfer antimicrobial resistance markers along with adhesion genes. By transforming E. coli DH5a with plasmid DNA from strains A46 (pIS46), A66 (pIS66) and A102 (pIS102), we were able to demonstrate that genes encoding ampicillin, tetracycline and LAL were encoded on a 98-MDa conjugative plasmid. To identify a gene responsible for $L A L$, we constructed a transposon mutant library of A102 strain. Among 18 mutants that did not adhere to HeLa cells, four carried insertions within fimbrial genes (fimA and traJ) and agglutinin genes (tia and hek). Using these Tn5 mutants as donors, we were able to obtain kanamycinresistant E. coli MA3456 transconjugants. Sequence analysis of the plasmid genes revealed a region exhibit to 80 and $73 \%$ amino acid similarities to the agglutinins Tia and Hek, respectively.
\end{abstract}

Conclusion: In this study, we have identified three large conjugative plasmids, pIS46, pIS66 and pIS102, coding for antimicrobial resistance and localized-like adherence (LAL) to HeLa cells. In addition, we identified a tia/hek homolog encoded on the pIS102 plasmid, which seems to be involved in adhesion of A102 strain.

Keywords: Atypical enteropathogenic Escherichia coli, Localized adherence-like, Antimicrobial resistance, Plasmids

\section{Background}

Enteropathogenic Escherichia coli (EPEC) is a leading cause of infantile diarrhea in developing countries, including Brazil [1-3]. EPEC colonizes the small intestine, causing characteristic attaching and effacing $(\mathrm{A} / \mathrm{E})$ lesions in the intestinal epithelial cells. The genes necessary for the $\mathrm{A} / \mathrm{E}$ phenotype are located on a pathogenicity island

\footnotetext{
*Correspondence: scaletskyunifesp@gmail.com

Departamento de Microbiologia, Imunologia e Parasitologia, Universidade Federal de São Paulo, Escola Paulista de Medicina, Rua Botucatu, 862, 3 andar, São Paulo 04023-062, Brazil
}

named the locus of enterocyte effacement (LEE), which encodes a type III secretion system and effectors, the outer membrane adhesin intimin and its translocated receptor (Tir) [4-6].

EPEC is divided into typical (tEPEC) and atypical (aEPEC) strains $[7,8]$. Typical EPEC strains carry a large virulence plasmid designated the EPEC adherence factor plasmid (pEAF) [9]. The pEAF plasmid encodes the bundle forming pilus (Bfp), which promote bacterium-tobacterium adherence, resulting in formation of compact microcolonies on the surface of HeLa/HEp-2 cells after

(c) The Author(s). 2020 Open Access This article is licensed under a Creative Commons Attribution 4.0 International License, which permits use, sharing, adaptation, distribution and reproduction in any medium or format, as long as you give appropriate credit to the original author(s) and the source, provide a link to the Creative Commons licence, and indicate if changes were made. The images or other third party material in this article are included in the article's Creative Commons licence, unless indicated otherwise in a credit line to the material. If material is not included in the article's Creative Commons licence and your intended use is not permitted by statutory regulation or exceeds the permitted use, you will need to obtain permission directly from the copyright holder. To view a copy of this licence, visit http://creativecommons.org/licenses/by/4.0/. The Creative Commons Public Domain Dedication waiver (http://creativecommons.org/publicdomain/zero/1.0/) applies to the data made available in this article, unless otherwise stated in a credit line to the data. 
$3 \mathrm{~h}$ of incubation, a phenotype known as localized adherence (LA) $[10,11]$. In contrast, atypical EPEC strains do not posses the pEAF plasmid, and are unable to produce LA. In the absence of Bfp, atypical EPEC strains display a variant LA pattern designated LA-like (LAL) pattern, which is characterized by the presence of compact microcolonies on HEp- 2 cells observed after $6 \mathrm{~h}$ of infection [12]. LAL is the most common pattern seen among aEPEC strains, however, some strains exhibit diffuse adherence (DA) or aggregative adherence (AA) patterns [13-15]. However, not much is known about the adherence factors involved with these phenotypes. In a previous study, we identified two factors contributing to the LAL phenotype of an aEPEC strain E. coli 22 (O26:NM) [16]. A novel afimbrial adhesin called the locus for diffuse adherence, $l d a$, which encodes a diffuse pattern of adherence on HEp-2 cells when cloned into a nonadherent E. coli K12 strain. A second plasmid-encoded factor that contributes to the compact microcolony formation of E. coli 22, but was not characterized.

Atypical EPEC is currently an emerging diarrheal pathogen in both developing and developed countries [17-20]. In previous studies, we have shown that classic aEPEC strains are important diarrheal pathogens among Brazilian children [21, 22]. In the characterization of a collection of 126 aEPEC strains, we identified 29 strains expressing the LAL pattern on HEp-2 cells [23]. Most of these strains belonged to the classical EPEC serotypes and carried one or two large plasmid bands in the range of 60 to $98 \mathrm{MDa}$. In this study, we sought to investigate whether these plasmids are involved in the LAL phenotype.

\section{Results}

\section{Examination of plasmids in aEPEC LAL ${ }^{+}$}

In this study, we examined $18 \mathrm{aEPEC} \mathrm{LAL}^{+}$strains harboring large plasmids and belonging to different serotypes for their ability to transfer the LAL phenotype to a E. coli K-12 strain. Strains were characterized for antibiotic resistance to ampicillin (Ap), tetracycline (Tc), chloramphenicol $(\mathrm{Cm})$, kanamycin $(\mathrm{Km})$, and nalidixic acid (Nal), and screened for the presence of conjugal transfer (tra) genes. Among the $18 \mathrm{LAL}^{+}$aEPEC strains, 12 were resistant to one or more antimicrobials, and eight of these were positive for F-pili genes $(\operatorname{tra} A)$ (Table 1).

To test for the presence of LAL plasmids, we perfomed conjugation experiments with the resistant traApositive strains and the plasmidless non-adherent $E$. coli K-12 C600 strain. As shown in Table 1, all eight traApositive strains transferred multiple antibiotic resistance to E. coli C600 strain. The transfer frequencies were low in the range between $10^{-6}$ and $10^{-9}$. Using two transconjugants of each pattern in a HeLa cell adhesion assay we found that only transconjugants from A46 (O55:
HND), A66 (O119:HND) and A102 (ONT:HND) strains exhibited the LAL phenotype (Fig. 1).

Strain A46 carries two plasmids, one of about $60-\mathrm{MDa}$ and another of $98-\mathrm{MDa}$, being only the larger plasmid the conjugative. The phenotype of donor strain and transconjugant was $\mathrm{Ap}^{\mathrm{r}} \mathrm{Tc}^{\mathrm{r}}$ LAL (Fig. 1a). Strain A66 harbors only one large conjugative plasmid of about 98MDa encoding for $\mathrm{Ap}^{\mathrm{r}} \mathrm{Tc}^{\mathrm{r}}$ LAL (Fig. 1b). Strain A102 contain only one large conjugative plasmid of about 98$\mathrm{MDa}$ encoding for $\mathrm{Ap}^{\mathrm{r}} \mathrm{Tc}^{\mathrm{r}}$ LAL (Fig. 1c). Southern blot hybridization with traA genes detected restriction fragments of $2.5-\mathrm{kb}$ in pIS46 and pIS66 plasmids and 1.4-kb in A102 strain, and revealed different profiles (Fig. 2).

In order to confirm the presence of LAL plasmids, the transconjugant plasmids from strains A46 (pIS46), A66 (pIS66), and A102 (pIS102) were transformed into E. coli K-12 DH5 $\alpha$, as described elsewhere [25]. The resulting transformants carrying pIS46, pIS66, or pIS102, were used as donors in a second conjugation experiment with E. coli $\mathrm{K}-12 \mathrm{~J} 53$ as the recipient strain. The seletive plates were minimal medium A [26] containing ampicillin and tetracycline. All $\mathrm{Ap}^{\mathrm{r}} \mathrm{Tc}^{\mathrm{r}}$ transconjugants showed LAL phenotype.

Nwaneshiudu et al. [27] identified a large conjugative multidrug resistance plasmid in an aEPEC O119:H2 strain MB80. After, we identified variants of the MB80 conjugative resistance in other EPEC strains [28]. In this

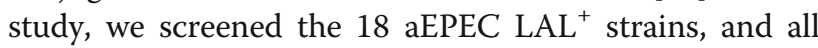
tested negative for the pMB80 traI and traC PCRs.

\section{Identification of genes involved in LAL phenotype}

To identify alternative adhesins to Bfp in aEPEC, we studied strain A102. To identify genes involved in LAL phenotype, we mutagenized strain A102 with the EZ:: $\mathrm{TN}<\mathrm{R} 6 \mathrm{~K}$ rori/KAN-2 $>$ Tnp transposome, and screened for adhesion-defective mutants. Among 1100 transposon-inserted mutants screened, 18 mutants that did not adhere to HeLa cells were isolated. All these 18 mutants showed growth rates comparable to those of the parent strains (data not shown). The transposoninserted locus of each mutant was cloned, as described in Material and Methods, and insertion flanking regions were sequenced. Fourteen transposon insertions were located in genes associated with amino acid metabolism, outer membrane proteins, transcriptional regulators, DNA enzymes, and transport system. Transposon in four mutants were found within fimbrial genes (fim $A$ and traJ) and agglutinin genes (tia and hek) (Table 2).

In this study, we demonstrated that the pIS102 plasmid confers LAL pattern in HeLa cells when expressed in $E$. coli $\mathrm{K}-12$, and we suspected that the agglutinin genes were located on this plasmid. Thus, we attempted to transfer the agglutinin genes (containing the Tn5kanamycin) from the mutants II-A-7 and II-F-5 into a 
Table 1 Results of conjugation between $\mathrm{LAL}^{+}$aEPEC strains and E. coli K-12 C600

\begin{tabular}{|c|c|c|c|c|c|c|c|c|}
\hline $\begin{array}{l}\text { aEPEC } \\
\text { strain }\end{array}$ & Source & Serotype & $\begin{array}{l}\text { Resistance } \\
\text { profile }^{a}\end{array}$ & $\begin{array}{l}\text { Size (MDa) of } \\
\text { plasmid(s) }\end{array}$ & $\begin{array}{l}\text { Presence }(+) \text { or } \\
\text { absence }(-) \text { of traA }\end{array}$ & $\begin{array}{l}\text { Resistance profile of } \\
\text { transconjugant(s) }\end{array}$ & $\begin{array}{l}\text { Size }(\mathrm{MDa}) \text { of } \\
\text { transconjugant } \\
\text { plasmid(s) }\end{array}$ & $\begin{array}{l}\mathrm{LAL} \\
\text { phenotype }\end{array}$ \\
\hline A1 & Diarrhea & O26:NM & - & $\sim 60,4.6$ & - & - & - & - \\
\hline A24 & Diarrhea & O26:NM & $A p^{r}$ & 98 & + & $\mathrm{Ap}^{r} \mathrm{Nal} l^{r}$ & 98 & - \\
\hline A14 & Diarrhea & $\begin{array}{l}\text { O26: } \\
\text { HND }\end{array}$ & $\mathrm{Km}^{r} \mathrm{Nal}{ }^{r}$ & $98, \sim 60$ & - & - & - & - \\
\hline A72 & Diarrhea & $\begin{array}{l}\text { O26: } \\
\text { HND }\end{array}$ & $\mathrm{Km}^{r} \mathrm{Nal}{ }^{r}$ & $\sim 60$ & - & - & - & - \\
\hline A153 & Diarrhea & $\begin{array}{l}\text { O26: } \\
\text { HND }\end{array}$ & - & $98,<4.6$ & + & - & - & - \\
\hline A46 & Diarrhea & $\begin{array}{l}\text { O55: } \\
\text { HND }\end{array}$ & $A p^{r} K m^{r} T C^{r}$ & $\sim 60,98$ & + & $\mathrm{Ap}^{r} \mathrm{TC}^{r} \mathrm{Nal}{ }^{r}$ & 98 & + \\
\hline A76 & Diarrhea & O85:H40 & $A p^{r} \mathrm{Cm}^{r}$ & $\sim 60$ & + & $\mathrm{Ap}^{r} \mathrm{Cm}^{\mathrm{r}} \mathrm{Nal}{ }^{r}$ & 98 & - \\
\hline A17 & Control & O105:H7 & - & $\sim 60$ & + & - & - & - \\
\hline A12 & Control & $\begin{array}{l}\text { O111: } \\
\text { NM }\end{array}$ & $\mathrm{Km}^{\mathrm{r}} \mathrm{Nal}{ }^{r}$ & $75,4.6$ & - & - & - & - \\
\hline A60 & Diarrhea & O119:H2 & - & 98 & + & - & - & - \\
\hline A66 & Diarrhea & $\begin{array}{l}\text { O119: } \\
\text { HND }\end{array}$ & $A p^{r} T c^{r}$ & 98 & + & $\mathrm{Ap}^{r} \mathrm{TC}^{r} \mathrm{Nal}{ }^{r}$ & 98 & + \\
\hline A13 & Diarrhea & $\begin{array}{l}\text { O126: } \\
\text { NM }\end{array}$ & - & $65,<4.6$ & - & - & - & - \\
\hline A11 & Diarrhea & $\begin{array}{l}\text { O142: } \\
\text { NM }\end{array}$ & - & $65,4.6$ & + & - & - & - \\
\hline A104 & Diarrhea & ONT:H18 & $A p^{r} T C^{r}$ & $>98$ & + & $\left.\mathrm{Ap}^{r} \mathrm{TC}^{\mathrm{r}} \mathrm{Nal}\right|^{r}$ & $>98$ & - \\
\hline A106 & Diarrhea & ONT:H18 & $A p^{r} C m^{r} T c^{r}$ & $>98$ & + & $A p^{r} T c^{r} N a l^{r}$ & $>98$ & - \\
\hline A10 & Diarrhea & $\begin{array}{l}\text { ONT: } \\
\text { HND }\end{array}$ & - & $>98$ & + & - & - & - \\
\hline A102 & Diarrhea & $\begin{array}{l}\text { ONT: } \\
\text { HND }\end{array}$ & $A p^{r} K m^{r} T c^{r}$ & 98 & + & $\mathrm{Ap}^{r} \mathrm{TC}^{\mathrm{r}} \mathrm{Nal}{ }^{r}$ & 98 & + \\
\hline A128 & Diarrhea & $\begin{array}{l}\text { ONT: } \\
\text { HND }\end{array}$ & $A p^{r} T c^{r}$ & 98 & + & $\mathrm{Ap}^{r} \mathrm{TC}^{r} \mathrm{Nal}{ }^{r}$ & 98 & - \\
\hline
\end{tabular}

${ }^{a} \mathrm{Ap}^{\mathrm{r}}$, ampicillin resistant; $\mathrm{Km}^{\mathrm{r}}$, kanamycin resistant; $\mathrm{Cm}^{\mathrm{r}}$, chloramphenicol resistant; $\mathrm{Tc}^{\mathrm{r}}$, tetracycline resistant; Nal ${ }^{\mathrm{r}}$, nalidicix acid resistant

${ }^{\mathrm{b}}$ The size of plasmids was calculated based on relative migration of plasmids with known sizes contained in strain 39-R861 [24]

nalidixic acid-resistant plasmidless $E$. coli MA3456. Indeed, we were able to obtain kanamycin-resistant $E$. coli MA3456 transconjugants using the Tn5 mutant II-A-7 as donor. Plasmid genes flanking the Tn5-transposon insertion were cloned, and a $1200 \mathrm{bp} E c o$ RI fragment containing Tn5 was subjected to DNA sequence. BLAST analysis identified a protein of 123 aminoacids with $80 \%$ identity to Tia and 73\% identity to Hek (Fig. 3; see Figure $\mathrm{S} 1$ in the supplemental material).

\section{Discussion}

The frequency of isolation of aEPEC from diarrheal cases has significantly increased in Brazil in the last years [1-3]. Atypical EPEC strains lack the EAF plasmid and hence are Bfp negative, but they can still adhere to HEp2 cells in a Bfp independent LA pattern, which is referred to as LAL [12]. The LAL pattern is characterized by the presence of compact microcolonies on HEp-2 cells, but only after $6 \mathrm{~h}$ of incubation, whereas LA is apparent after $3 \mathrm{~h}$.

In the search for potential adherence factors, we studied 18 atypical aEPEC $\mathrm{LAL}^{+}$strains isolated in a case control study in Brazil [23]. All of the 18 strains harbor one or two large plasmids and many genes encoding for known $E$. coli adhesins, but to date, no adhesive structure has been implicated in the microcolonies formation of aEPEC [23].

Our results demonstrate a high rate of resistance to certain antimicrobial agents in $12 \mathrm{aEPEC} \mathrm{LAL}^{+}$strains in which resistance is apparently associated with conjugative plasmids. In addition, we also found plasmids encoding multiple drug resistance along with adhesion genes in three aEPEC strains. By transforming E. coli DH5 $\alpha$ with plasmids from A46, A66 and A102 strains, we were able to demonstrate that genes encoding ampicillin and tetracycline resistance and LAL were encoded 

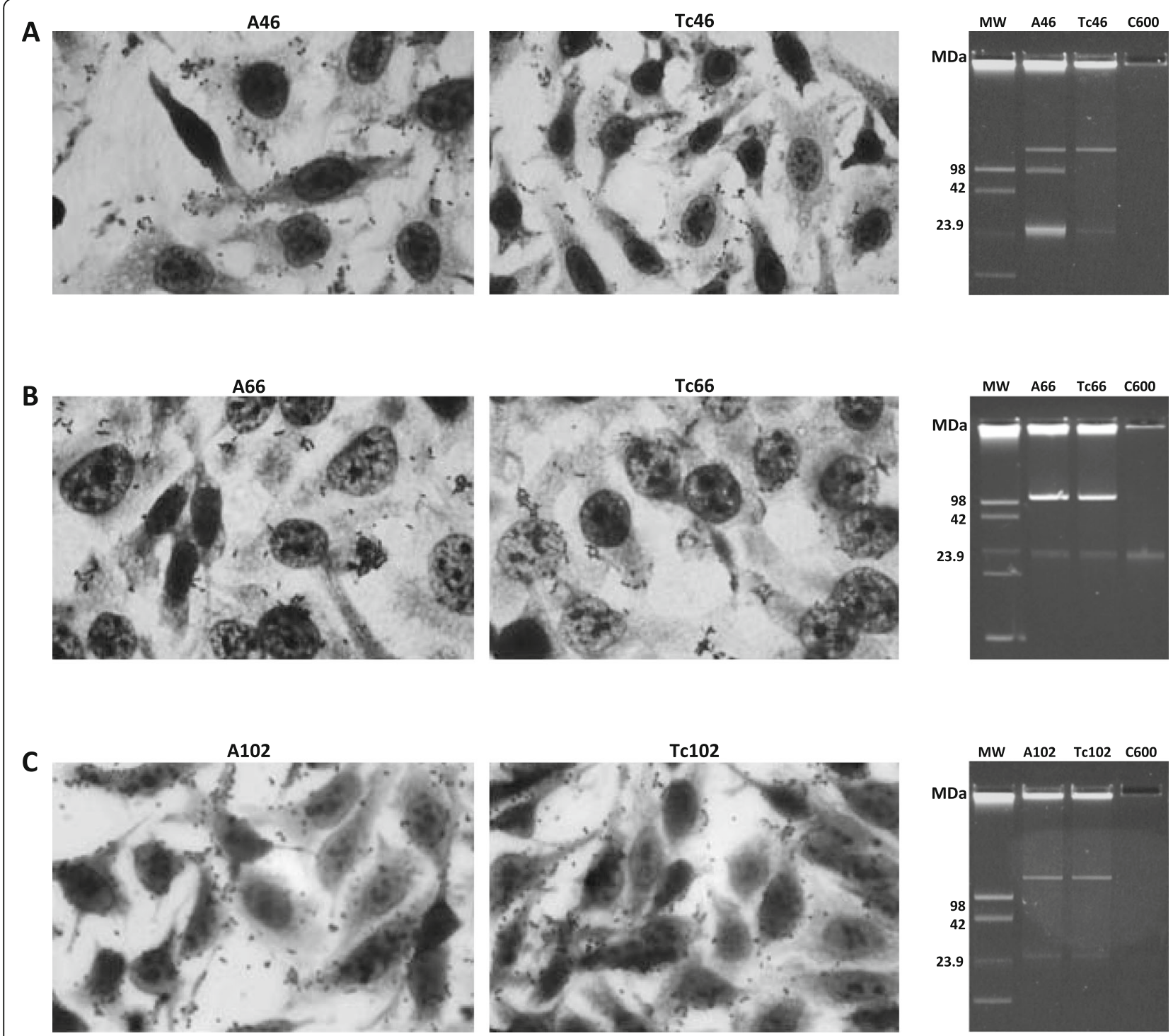

Fig. 1 HeLa cell adherence assay and plasmid profiles of the aEPEC and transconjugant strains. Light microscopy micrographs at $3 \mathrm{~h}$ after infection showing the localized-like adherence (LAL) (original magnification, 400x). a aEPEC A46 and transconjugant, b aEPEC A66 and transconjugant, and (c) aEPEC A102 and transconjugant. C600, a non-adherent and plasmidless E. coli K12 strain. MW, 39-R861strain carrying plasmids of known molecular sizes [24]

on a 98-MDa conjugative plasmid. Although an aEPEC conjugative multiresistance plasmid has been described [27], a plasmid coding for antibiotic resistance along with adhesion genes has not been previously reported in aEPEC.

In this study, we used Tn5-based transposon mutagenesis to identify the genetic determinants of aEPEC A102 strain responsible for the LAL phenotype. We have found that multiple factors, such as amino acid metabolism, transcriptional regulators, or transport systems may affect the adherence of A102 strain to HeLa cells. However, we identified mutated genes associated with fimbrial adhesins (fimA and traJ) and agglutinin genes (tia and hek), which suggest a role of these genes in adherence.

The fimbrial gene $\operatorname{fim} A$ encodes the larger subunit of type 1 pilus (T1P). T1P has been reported to be responsible for the initial adherence of $E$. coli $\mathrm{K}-12$ to abiotic surfaces [29], and is an important virulence factor in uropathogenic E. coli strains [30, 31]. However, T1P of prototype typical EPEC strains E2348/69 and B171 had no effect on LA pattern [32] but were important for development of the AA pattern on EAEC strain 042 [33]. The traJ gene regulates the expression of $F$ pilus involved in bacterial conjugation mediated by $\mathrm{F}$ plasmids [34]. It has been shown that putative F pilus may work 


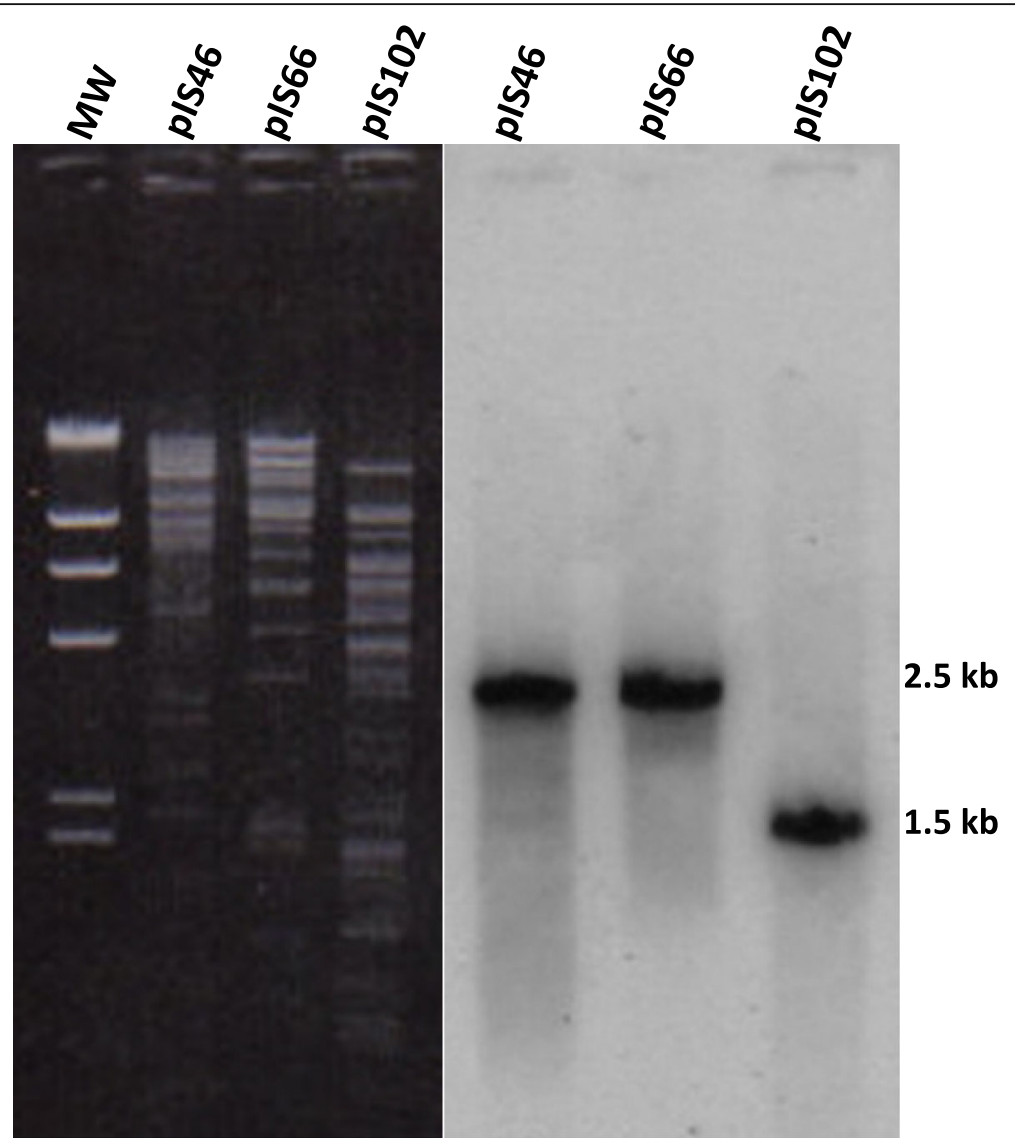

Fig. 2 Southern blotting analysis of transconjugant plasmids from strains A46 (plS46), A66 (plS66), and A102 (plS102) after digestion with EcoRI using the traA gene as a probe. MW, N/Hindlll molecular marker

Table 2 Transposon mutagenesis results for strain A102

\begin{tabular}{lll}
\hline Mutant strain & Gene function & $\%$ amino acid identity \\
\hline II-H-9 & Autotransporter outer membrane beta-barrel domain-containing protein & $100 \%$ \\
X-F-12 & Nitric oxide reductase [Escherichia coli] & $100 \%$ \\
III-C-1 & Lysine descarboxilase [Escherichia coli B088] & $100 \%$ \\
III-A-5 & Aspartokinase/Homoserine dehydrogenase [Escherichia coli ISC7] & $100 \%$ \\
X-A-12 & Oligogalacturonate lyase [Escherichia coli] & $100 \%$ \\
I-D-4 & GTP-binding protein, partial [Escherichia coli] & $100 \%$ \\
III-H-12 & Electron transfer flavoprotein, partial [Escherichia coli] & $100 \%$ \\
II-E-4 & ABC transporter ATP-binding protein [Enterobacteriaceae] & $99 \%$ \\
II-E-5 & Fimbrial protein [Escherichia coli H120] & $99 \%$ \\
V-A-1 & DeoR Family transcriptional regulator & $99 \%$ \\
IV-B-7 & Sodium/proline symporter [Escherichia coli] & $99 \%$ \\
II-C-7 & draP [Escherichia coli LAU-EC10] & $96 \%$ \\
II-E-4 & Hypothetical protein, partial & $80 \%$ \\
II-A-7 & Tia invasion determinant domain protein [Escherichia coli] & $80 \%$ \\
II-H-5, X-B-12 & ABC transporter ATP-binding protein [Escherichia coli] & \\
II-F-5 & Adhesin/Virulence fator Hek [Escherichia coli] & $75 \%$ \\
II-D-10 & Protein TraJ (Positive regulator of conjugal transfer operon) (Plasmid) [Escherichia coli S88] & $73 \%$
\end{tabular}




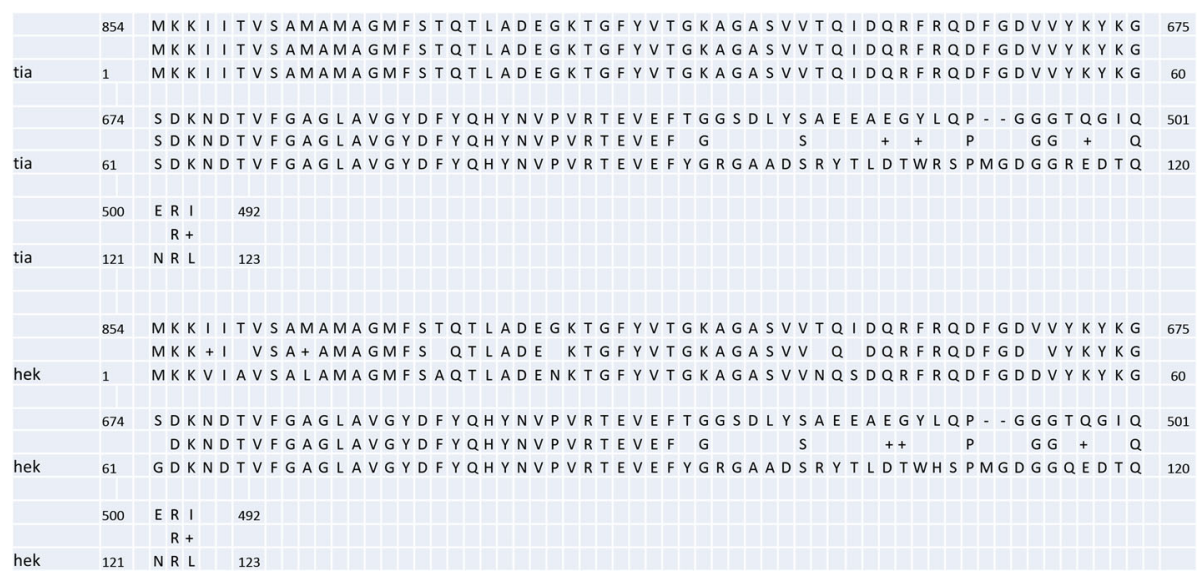

Fig. 3 Alignment of the deduced amino acid sequence of the $1175 \mathrm{pb}$ fragment and the tia invasion determinant and the adhesin/virulence factor Hek

as central adhesion factor during the biofilm formation by typical EAEC strains. In addition, $\mathrm{F}$ pili expressed by EAEC strains boosted mixed biofilm formation when in the presence of aggregative Citrobacter freundii [35].

The outer membrane invasin and adhesin Tia previously described in enterotoxigenic $E$. coli mediates bacterial attachment to a variety of cultured human epithelial cells, autoaggregation, and biofilm formation [36]. The Hek outer membrane protein of $E$. coli is an auto-aggregating adhesin and invasin reported from uropathogenic E. coli and neonatal meningitic E. coli $[37,38]$. Interestingly, agglutinin genes are common in aggregative E. coli (EAEC). EAEC strains harbor the agglutinin genes hra1 (hek), hra2 and tia which confer autoaggregation, biofilm formation, and AA patterns $[39,40]$. In this study, we were able to demonstrate that these agglutinin genes were encoded on the pIS102 plasmid. By using the Tn5 mutants as donors, we were able to obtain kanamycin-resistant $E$. coli MA3456 transconjugants. Sequence analysis of the plasmid genes revealed a region exhibit to 80 and $73 \%$ amino acid similarities to the agglutinins Tia and Hek, respectively. Future efforts will be directed to construct a tia/kek homolog deletion mutant of A102 strain.

\section{Conclusions}

In this study, we have identified three large conjugative plasmids, pIS46, pIS66 and pIS102, coding for antimicrobial resistance and localized-like adherence (LAL) to HeLa cells. In addition, we identified a tia/hek homolog encoded on the pIS102 plasmid, which seems to be involved in adhesion of A102 strain. Characterization of this tia/hek homolog may bring new insights into aEPEC colonization.

\section{Methods}

\section{Bacterial strains}

Eighteen aEPEC strains showing LAL and belonging to different serotypes were studied [23]. All strains were isolated from children with diarrhea. The E. coli $\mathrm{K}-12$ strains C600, J53 and DH 5 , and E. coli MA3456 were used as the recipient for EPEC plasmids during conjugation or transformation experiments. E. coli $\mathrm{DH} 5 \alpha \lambda$ pir was used for cloning studies. The strains were cultured in Luria-Bertani (LB) broth or on $\mathrm{LB}$ agar at $37^{\circ} \mathrm{C}$ with appropriate antibiotics when necessary.

\section{Antimicrobial susceptibility testing}

Antimicrobial susceptibility tests were performed by the disk diffusion method [41] using disks containing ampicillin $(10 \mu \mathrm{g})$, chloramphenicol $(30 \mu \mathrm{g}), \quad$ kanamycin $(30 \mu \mathrm{g})$, nalidixic acid $(30 \mu \mathrm{g})$, sulfonamide $(300 \mu \mathrm{g})$, streptomycin $(10 \mu \mathrm{g})$, and tetracycline $(30 \mu \mathrm{g})$. The inhibition zone diameters were interpreted according to Clinical and Laboratory Standards Institute requirements [41], and the E. coli NCTC10418 was used as the control.

\section{HeLa cell adherence assay}

The HeLa cell adhesion assay was performed as previously described [12] with modifications. Briefly, monolayers of $10^{5} \mathrm{HeLa}$ cells were grown in Dulbecco modified Eagle medium containing $10 \%$ fetal bovine serum, by use of 24well tissue culture plates. Bacteria strains were grown statically in $2 \mathrm{ml}$ of $\mathrm{LB}$ for $16-18 \mathrm{~h}$ at $37^{\circ} \mathrm{C}$. Cell monolayers were infected with $20 \mu \mathrm{l}$ of bacterial cultures added to 1 $\mathrm{ml}$ of DMEM and were incubated at $37^{\circ} \mathrm{C}$ for $3 \mathrm{~h}$. After incubation, the cells were washed with sterile PBS, fixed with methanol, stained with Giemsa stain, and examined under a light microscope.

\section{Plasmid profiling}

Plasmid DNA was extracted from overnight bacterial cultures by the alcaline extraction method of Birnboim and Doly [42], and analyzed in $0.8 \%$ agarose gels stained with ethidium bromide $(5 \mu \mathrm{g} / \mathrm{ml})$. Plasmid molecular sizes were calculated based on relative migration of plasmids with known sizes contained in strain 39-R861 [24]. 


\section{DNA hybridization}

Colony and Southern blot hybridization [25] were performed at $65^{\circ} \mathrm{C}$. Gene probes, $\operatorname{traA}$ [27] were generated by PCR, gel purified, and labeled with $\left[\alpha-{ }^{32} \mathrm{P}\right] \mathrm{dCTP}$ using a Rediprime (Amersham Pharmacia Biotech Inc., EUA) according to the manufacturer-s instructions.

\section{Conjugation experiments}

The donor and recipient strains were grown on LB broth to an optical density at $600 \mathrm{~nm}\left(\mathrm{OD}_{600}\right)$ of $0.5 \mathrm{mixed}$ equally, and then inoculated on filter papers for $4 \mathrm{~h}$. The filter paper mixtures were then suspended in LB medium, and dilutions were plated on LB agar containing nalidixic acid $(50 \mu \mathrm{g} / \mathrm{ml})$ with either ampicillin $(100 \mu \mathrm{g})$, kanamycin $(50 \mu \mathrm{g})$, chloramphenicol $(50 \mu \mathrm{g} / \mathrm{ml})$ or tetracycline $(25 \mu \mathrm{g} / \mathrm{ml})$. Conjugation frequencies were calculated as the ratio of number of transconjugant colonies by the number of donor colonies. Each conjugation experiment was repeated at least twice. The transconjugants were tested for HeLa cell adherence assay as described previously [12].

\section{Transposon mutagenesis and genetic analysis}

Transposon mutants were generated with the kanamycin resistance $\left(\mathrm{Km}^{\mathrm{r}}\right)$-encoding transposome EZ::TN $<$ R6Kyori/KAN-2> Tnp transposome (Epicentre Biotechnologies) by electroporation according to the manufacturer's procedures. Briefly, electrocompetent bacterial cells were transformed with $1 \mu \mathrm{l}$ of the Tnp transposome. Transposon-inserted bacterial colonies that grew on LB agar plates containing nalidixic acid $(100 \mu \mathrm{g} / \mathrm{ml})$, ampicillin $(100 \mu \mathrm{g} / \mathrm{ml})$ and kanamycin $(50 \mu \mathrm{g} / \mathrm{ml})$ were screened for their adhesion phenotype to HeLa cells as described below. Genomic DNA was isolated from mutants by using the PureLink Genomic DNA Mini kit (Invitrogen). Genomic DNA of the mutants, was digested with EcoRI, self-ligated by the addition of T4 DNA ligase, and then used for transformation of $E$. coli DH5 $\alpha \lambda$ pir. Rescued DNA plasmids were purified by using the Mini plasmid kit (Qiagen) and sequenced by using transposon-specific primers R6KAN-2 RP-1 and KAN-2 FP-1 (Epicentre). DNA sequencing was performed at the Centro de Estudos do Genoma HumanoUSP, São Paulo. Nucleotide sequence data were analyzed using SeqMan and MegAlign software and the BLAST tool (http://www.ncbi.nlm.nih.gov/BLAST).

\section{Supplementary information}

Supplementary information accompanies this paper at https://doi.org/10. 1186/s12866-020-01809-4.

Additional file 1 : Figure S1 BLAST results of the $1175 \mathrm{bp}$ sequence obtained from transconjugant II-A-7. Description of data: Descriptions and alignments of the $1175 \mathrm{pb}$ sequence.

\section{Abbreviations}

EPEC: Enteropathogenic Escherichia coli; tEPEC: typical EPEC; aEPEC: atypical EPEC; LA: Localized adherence; LAL: Localized adherence-like; DA: Diffuse adherence; AA: Aggregative adherence; EAF: E. coli adherence factor plasmid: BFP: Bundle-forming pilus; TIP: Type 1 pili

\section{Acknowledgments}

This study was supported by Fundação de Amparo à Pesquisa do Estado de São Paulo (FAPESP) and Conselho Nacional de Desenvolvimento Científico e Tecnológico (CNPq).

\section{Authors' contributions}

SSS performed the genetic experiments and MVM analyzed data and contributed to the preparation of the manuscript. ICAS designed the experimental procedures, supervised all the experimental works and wrote the manuscript. All authors read and approved the final manuscript.

\section{Funding}

No funding was obtained for this study.

\section{Availability of data and materials}

The data is available upon request. Please contact the corresponding author Isabel C A Scaletsky, E-mail: scaletskyunifesp@gmail.com

\section{Ethics approval and consent to participate}

The study was approved by the ethics committee of the Universidade Federal de São Paulo, Brazil. Stool samples were obtained with the written informed consent from the parents or guardians of the children.

\section{Consent for publication}

Not Applicable.

\section{Competing interests}

The authors declare that they have no competing interests.

Received: 18 December 2019 Accepted: 30 April 2020

Published online: 29 May 2020

\section{References}

1. Nataro JP, Kaper JB. Diarrheagenic Escherichia coli. Clin Microbiol Rev. 1998; 11:142-201.

2. Ochoa TJ, Contreras CA. Enteropthogenic Escherichia coli infection in children. Curr Opin Infect Dis. 2011;24:478-83.

3. Kotloff KL, Nataro JP, Blackwelder WC, et al. Burden and aetiology of diarrhoeal disease in infants and young children in developing countries (the global enteric multicenter study, GEMS): a prospective, case-control study. Lancet. 2013;382:209-22.

4. Moon HW, Whipp SC, Argenzio RA, Levine MM, Gianella RA. Attaching and effacing activities of rabbit and human enteropathogenic Escherichia coli in pig and rabbit intestines. Infect Immun. 1983;41:1340-51.

5. Jarvis KG, Girón JA, Jerse AE, McDaniel TK, Donnenberg MS, Kaper JB. Enteropathogenic Escherichia coli contains a putative type III secretion system necessary for the export of proteins involved in attaching and effacing lesion formation. Proc Natl Acad Sci U S A. 1995;92:7996-8000.

6. McDaniel TK, Kaper JB. A cloned pathogenicity island from enteropathogenic Escherichia coli confers the attaching and effacing phenotype on E. coli K12. Mol Microbiol. 1997;23:399-407.

7. Kaper JB. Defining EPEC. Rev Microbiol. 1996;27:130-3.

8. Trabulsi LR, Keller R, Gomes TAT. Typical and atypical enteropathogenic Escherichia coli. Emerg Infect Dis. 2002;8:508-13.

9. Baldini MM, Kaper JB, Levine MM, Candy DC, Moon HW. Plasmid-mediated adhesion in enteropathogenic Escherichia coli. J Pediatr Gastroenterol Nutr. 1983:2:534-9.

10. Donnenberg MS, Girón JA, Nataro JP, Kaper JB. A plasmid-encoded type IV fimbrial gene of enteropathogenic Escherichia coli associated with localized adherence. Mol Microbiol. 1992;6:3427-37.

11. Scaletsky ICA, Silva MLM, Trabulsi LR. Distinctive patterns of adherence of enteropathogenic Escherichia coli to HeLa cells. Infect Immun. 1984; 45:534-6.

12. Scaletsky ICA, Pelayo JS, Giraldi R, Rodrigues J, Pedroso MZ, Trabulsi LR. EPEC adherence to HEp-2 cells. Rev Microbiol. 1996;27:58-62. 
13. Scaletsky ICA, Pedroso MZ, Oliva CAG, Carvalho RLB, Morais MB, Fagundes Neto U. A localized adherence-like pattern as a second pattern of adherence of classic enteropathogenic Escherichia coli to HEp-2 cells that is associated with infantile diarrhea. Infect Immun. 1999:67:3410-5.

14. Abe CM, Trabulsi LR, Blanco J, Blanco M, Dahbi G, Blanco JE, Mora A, Franzolin MR, Taddei CR, Martinez MB, et al. Virulence features of atypical enteropathogenic Escherichia coli identified by the eae+ EAF-negative stxgenetic profile. Diagn Microbiol Infect Dis. 2009;64:357-65.

15. Tennant SM, Tauschek M, Azzopardi K, Bigham A, Bennette-Wood V, Hartland EL, et al. Characterization of atypical enteropathogenic E. coli strains of clinical origin. BMC Microbiol. 2009;2009(3):9-117.

16. Scaletsky ICA, Michalski J, Torres AG, Dulguer MV, Kaper JB. Identification and characterization of the locus for diffuse adherence, which encodes a novel afimbrial adhesion found in atypical enteropathogenic Escherichia coli. Infect Immun. 2005;73:4753-65.

17. Robins-Browne Afset JE, Bevanger L, Romundstad P. Bergh, K: association of atypical enteropathogenic Escherichia coli (EPEC) in prolonged diarrhea. J Med Microbiol. 2004;53:1137-44.

18. Alikhani MY, Mirsalehian A, Aslani MM. Detection of typical and atypical enteropathogenic Escherichia coli (EPEC) in Iranian children with and without diarrhoea. J Med Microbiol. 2006;146:54-61.

19. Robins-Browne RM, Bordun A, Tauschek M, Bennett-Wood TM, Russell J, Oppedisano F, et al. Escherichia coli and community-acquired gastroenteritis, Melbourne, Australia. Emerg Infect Dis. 2004;101:1797-805.

20. Nguyen RN, Taylor L, Tauschek M, Robins-Browne RM. Atypical enteropathogenic Escherichia coli infection and prolonged diarrhea in children. Emerg Infect Dis. 2006;12:597-603.

21. Araújo JM, Tabarelli GF, Aranda KR, Fabbricotti SH, Fagundes-Neto U, Scaletsky ICA. Typical enteroaggregative and atypical enteropathogenic types of Escherichia coli are the most prevalent diarrhea-associated pathotypes among Brazilian children. J Clin Microbiol. 2007;45:3396-9.

22. Scaletsky ICA, Aranda KR, Souza TB, Silva NP, Morais MB. Evidence of pathogenic subgroups among atypical enteropathogenic Escherichia coli strains. J Clin Microbiol. 2009;47:3756-9.

23. Scaletsky IC, Aranda KR, Souza TB, Silva NP. Adherence factors in atypical enteropathogenic Escherichia coli strains expressing the localized adherence-like pattern in HEp-2 cells. J Clin Microbiol. 2010a;48:302-6.

24. Threlfall EJ, Rowe B, Ferguson JL, Ward LR. Characterization of plasmids conferring resistance to gentamicin and apramycin in strains of Salmonella typhimurium phage type 204C isolated in Britain. J Hyg (Lond). 1986;97:419-26.

25. Sambrook J, Fritsch EF, Maniatis T. Molecular cloning: a laboratory manual. 2nd ed. Cold Spring Harbor, NY: Cold Spring Harbor Laboratory Press; 1989.

26. Davis BD, Mingioli ES. Mutants of Escherichia coli requiring methionine or vitamin B12. J Bacteriol. 1950;60:17-28.

27. Nwaneshiudu Al, Mucci T, Pickard DJ, Okeke IN. A second large plasmid encodes conjugative transfer and antimicrobial resistance in $\mathrm{O} 119: \mathrm{H} 2$ and some typical 0111 enteropathogenic Escherichia coli strains. J Bacteriol. 2007;189:6074-9.

28. Scaletsky ICA, Souza TB, Aranda KRS, Okeke IN. Genetic elements associated with antimicrobial resistance in enteropathogenic Escherichia coli (EPEC) from Brazil. BMC Microbiol. 2010b;10:25.

29. Pratt $L A$, Kolter R. Genetic analysis of Escherichia coli biofilm formation: roles of flagella, motility, chemotaxis and type 1 pili. Mol Microbiol. 1998;30:28593.

30. Johnson JR. Virulence factors in Escherichia coli urinary tract infection. Clin Microbiol Rev. 1991;4:80-128.

31. Connell I, Agace W, Klenm P, Schembri M, Marild S, Svanborg C. Type 1 fimbria expression enhances Escherichia coli virulence for the urinary tract. Proc Natl Acad Sci U S A. 1996;93:9827-32

32. Elliott $\mathrm{S}$, Kaper JB. Role of type 1 fimbriae in EPEC infections. Microb Pathol. 1997:23:113-8.

33. Moreira CG, Carneiro SM, Nataro JP, Trabulsi LR, Elias WP. Role of type 1 fimbrae in the aggregative adhesion pattern o enteroaggregative Escherchia coli. FEMS Microbiol Lett. 2003;226:79-85.

34. May T, Okabe S. Escherichia coli harboring a natural IncF conugative $F$ plasmid develops complex mature biofilms by stimulating synthesis of colanic and curli. J Bacteriol. 2008;190:7479-90.

35. Pereira AL, Silva TN, Gomes ACMM, Araújo ACG, Giugliano LG. Diarrheaassociated biofilm formed by enteroaggregative Escherichia coli and aggregative Citrobacter freundii: a consortium mediated by putative F pili. BMC Microbiol. 2010;10:57.
36. Fleckenstein JM, Kopecko DJ, Warren RI. Elsinghorst: molecular characterization of the tia invasion locus from enterotoxigenic Escherichia coli. Infect Immun. 1996;64:2256-65.

37. Fagan RP, Lambert MA, Smith SG. The Hek outer membrane protein of Escherichia coli strain R218 binds to proteoglycan and utilizes a single extracelular loop for adherence, invasion and autoaggregation. Infect Immun. 2008;76:1135-42.

38. Srinivasan $U$, Foxman $B$, Marrs CF. Identification of a gene encoding heatresistant agglutinin in Escherichia coli as a putative virulence factor in urinary tract infection. J Clin Microbiol. 2003;41:285-9.

39. Bhargava S, Johnson BB, Hwang J, Harris TA, George AS, Muir A, Dorff J, Okeke IN. The heat-resistant agglutinin 1 is an acessory enteroaggregative Escherichia coli colonization fator. J Bacteriol. 2009;191:4934-42.

40. Mancini J, Weckselblatt B, Chung YK, Durante JC, Andelman S, Glaubman J, Dorff JD, Bhargava S, Lijek RS, Unger KP, Okeke IN. The resistant agglutinin family includes a novel adhesin from enteroaggregative Escherichia coli strain 60A. J Bacteriol. 2011:193:4813-20.

41. National Committee for Clinical Laboratory Standards. Performance standards for antimicrobial disk susceptibility tests: 8th edition. Villanova: National Committee for Clinical Laboratory Standards; 2003.

42. Birnboim HC, Doly J. A rapid alkaline extraction procedure for screening recombinant plasmid DNA. Nucleid Acids Res. 1979:7:1513-23.

\section{Publisher's Note}

Springer Nature remains neutral with regard to jurisdictional claims in published maps and institutional affiliations.
Ready to submit your research? Choose BMC and benefit from:

- fast, convenient online submission

- thorough peer review by experienced researchers in your field

- rapid publication on acceptance

- support for research data, including large and complex data types

- gold Open Access which fosters wider collaboration and increased citations

- maximum visibility for your research: over $100 \mathrm{M}$ website views per year

At BMC, research is always in progress.

Learn more biomedcentral.com/submissions 